
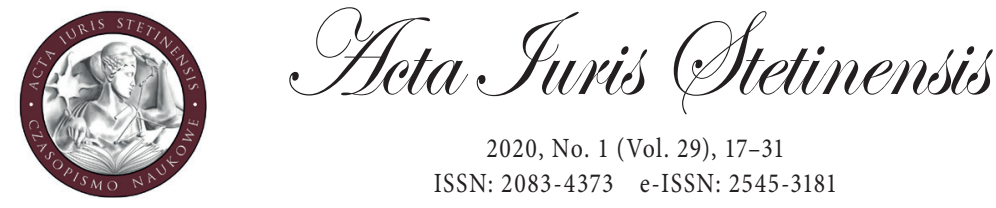

2020, No. 1 (Vol. 29), 17-31

ISSN: 2083-4373 e-ISSN: 2545-3181

DOI: $10.18276 /$ ais.2020.29-02

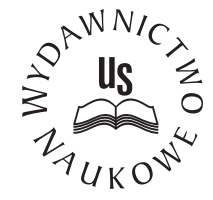

Konrad Graczyk

Ph. D.

University of Silesia in Katowice, Poland

Faculty of Law and Administration

e-mail: konrad.graczyk@us.edu.pl

OPEN ACCESS

ORCID ID: 0000-0002-0991-2036

\title{
Convicted Nazi lawyer. The case of Gerhard Pchalek in the Gera District Court in $1960^{1}$
}

\begin{abstract}
This study is devoted to a criminal case brought before a court in the German Democratic Republic against Gerhard Pchalek in connection with his service as a prosecutor in the Third Reich. Pchalek served in the Polish territories incorporated into the Reich, in Bielsko and Katowice. He was a prosecutor in proceedings before special courts in Bielsko and Katowice, as well as before the Higher National Court in Katowice, in which he filed motions to sentence defendants to the death penalty. In 20 cases - as was determined by the District Court in Gera - Pchalek demanded the death penalty, which was then imposed and enforced. His act was classified as aiding in murder under the provisions of the German Criminal Code, and Pchalek was sentenced to 4 years in strict regime prison. The paper discusses the biography of Pchalek, the issue of post-war criminal liability of Nazi lawyers and the criminal trial before the District Court in Gera. The study uses a historical, formal and dogmatic method. The criminal trial in question is one of the few cases in which a Nazi lawyer was convicted.
\end{abstract}

Keywords: Third Reich, criminal liability, crimes against humanity, judiciary, prosecutor

1 The paper was prepared under the research project financed by the National Science Centre in Poland (2017/27/N/HS5/00423). 


\section{Introduction}

The purpose of this study is to analyse the case of Gerhard Pchalek who was tried before the District Court in Gera. Pchalek served as a prosecutor during World War II in Polish lands incorporated into the Third Reich. As a prosecutor before special courts, he led to imposing the death penalty in a number of cases. Then, in the early 1960s, he himself was sentenced to 4 years in strict regime prison. Pchalek's case is a rare example of prosecuting a Nazi lawyer. The deliberations are based on Pchalek's personal files kept at the Federal Archives in Berlin (Bundesarchiv Berlin), in unit R 3001 Reichsjustizministerium and the criminal case files of 1959-1960 kept at the office of the Federal Commissioner for the Records of the State Security Service of the former German Democratic Republic, the Gera Branch (Bundesbeauftragte für die Unterlagen der Staatssicherheit der ehem. DDR Außenstelle Gera). Peter Riegel's study ${ }^{2}$ of Pchalek and Witold Kulesza's monograph on the crimes committed by judges and prosecutors were also used. ${ }^{3}$ It should be noted that the case of prosecutor Pchalek was omitted in the latter, important publication.

In order to better understand that nature of the criminal case before the court in the German Democratic Republic, it is worth describing who Gerhard Pchalek was and discussing the issue of the criminal liability of Nazi-era judges and prosecutors.

\section{Gerhard Pchalek - biographical sketch}

Gerhard Pchalek was born on 20 May 1910, in Załęże (currently a district of Katowice) in Upper Silesia, in a working-class family. His father had been a locksmith but had to change his job after an accident. During the Weimar Republic, he became a Commissioner of the criminal police and his family moved to Racibórz. In 1930, Gerhard Pchalek passed his secondary school graduation exam and enrolled to study law at the University in Graz. In 1934, he moved to the University in Wrocław, where he passed the first state examination in law with "satisfactory" grade (ausreichend). ${ }^{4}$ He got married in early $1936 .{ }^{5}$ From 25 October 1937 to 18

2 Riegel, P., Der Tiefe Fall des Professors Pchalek - Diener dreier Unrechtssysteme. Ein Thüringer Jurist zwischen NS-Justiz, Besatzungsmacht, Rechtsprofessur und Spitzeldienst, Erfurt 2007.

3 Kulesza, W., Crimen laesae iustitiae. Odpowiedzialność karna sędziów i prokuratorów za zbrodnie sądowe wedtug prawa norymberskiego, niemieckiego, austriackiego i polskiego, Łódź 2013.

4 Bundesarchiv Berlin (hereinafter: BA), R 3001 Reichsjustizministerium/70439, p. 5, Schreiben betr. Zulassung des Referendars Gerhard Pchalek vom 20. September 1938 [Letter on the admission of referendary Gerhard Pchalek of 20 September 1938].

5 Bundesbeauftragte für die Unterlagen der Staatssicherheit der ehem. DDR [Federal Commissioner for the Records of the State Security Service of the former German Democratic Republic, 
December 1937, he attended the Hanns Kerrl's camp (Gemeinschaftslager Hanns Kerrl), where trainee lawyers from different regions of the Reich could establish friendly relations with one another. At the end of the two-month camp, each participant received an opinion describing the traits of their character. ${ }^{6}$ Pchalek was evaluated as ambitious, diligent, hardworking and polite, though of excessive need for recognition and self-confidence and too fatherly towards his colleagues. ${ }^{7}$ Until 1938, he served his legal training in the courts of the region of the Higher National Court in Wrocław, e.g. in Głogów and Zielona Góra. ${ }^{8}$

In early 1939 in Berlin, he passed the grand national legal exam with satisfactory grade (befriedigend), ${ }^{9}$ which qualified him to serve as an assessor. The summary of his achievements contained contradictory recommendations of the General Prosecutor in Wrocław, Reinhold Sturm, PhD and the President of the Higher National Court in Wrocław, Walther Freiherr von Steinaecker, respectively. It was noted that two of his legal training supervisors were of a very positive opinion of him, although the camp commander's opinion was only average. Pchalek was regarded as a person of impeccable conduct and unquestionable political attitude. This was associated with his membership in the National Socialist Flyers Corps (NS-Fliegerkorps), the intention to admit him to the party through that organisation and completion of two eight-week military drills. The general prosecutor stated that Pchalek did not make a positive impression on him in any aspect of his presentation, that he was very self-confident, even to the point of being uncritical of himself, and, accordingly, he recommended not admitting him to service. The President of the Higher National Court in Wrocław assessed the candidate's qualifications as definitely above average and, despite certain doubts concerning his character, he

hereinafter: BStU] Außenstelle Gera [Gera branch], Ministerium für Staatssicherheit [Ministry for State Security; hereinafter: MfS]/Bezirksverwaltung [Regional Board] Gera, Archivierter Untersuchungsvorgang [Archived investigation case; hereinafter: AUV] 38/59, HA [Hauptakten Main files] Bd. II, p. 177, Schlussbericht vom 23. Juli 1959 [Final report of 23 July 1959]. The cited archival sources were analyzed by the author, they are not referred to in the publication of Peter Riegel.

6 Gruchmann, L., Justiz im Dritten Reich 1933-1940. Anpassung und Unterwerfung in der Ära Gürtner, München 2001, p. 303.

7 BA, R 3001/70439, p. 8, Zeugnis des Kommandanten des Gemeinschaftslagers Hanns Kerrl vom 18. Dezember 1937 [Testimony of camp commander Hanns Kerrl of 18 December 1937].

8 Riegel, P., op. cit., pp. 8-9, 11.

9 BA, R 3001/70439, pp. 10-11, Prüfungsprotokoll vom 9. Januar 1939 [Exam protocol of 9 January 1939]. 
recommended his admission. He expressed his hope that, during the preparatory service, the flaws of his character would be polished. ${ }^{10}$

By the end of June 1939, according to the recommendation of the President of the Higher National Court, Pchalek was admitted as a candidate to the judge and prosecutor office, and he obtained the title of a court assessor (Gerichtsassessor). ${ }^{11}$ He worked as an assessor in the prosecutor's office in Głogów, Gliwice and Wrocław and in the Circuit Court in Nowa Sól, Kowary, Ząbkowice Śląskie and Zabrze. ${ }^{12}$

Pchalek attended the abovementioned military drill from July to September 1935 and from March to May 1937. Because of military operations, he was drafted to Wermacht as a non-commissioned officer from 15 December 1939 to 8 September 1940 and from 7 February $1941 .{ }^{13}$ In May, he was discharged due to a heart disease. $^{14}$

In the meantime, from September 1940 to February 1941, he worked in prosecutor's offices in Racibórz and Bielsk. In July 1941, he was appointed by the Führer as prosecutor in the prosecutor's office at the National Court in Bielsk. ${ }^{15}$ Letters concerning reclaiming Pchalek's from military service suggest that he was very needed in Bielsko as a specialist in economic crime. It was also noted that the prosecutor's office in Bielsko played an important role in combatting Polish resistance and, in particular, active Polish offenders. Pchalek's superiors considered it necessary to release Pchalek from military service. ${ }^{16}$ The military authorities consented to temporary reclaiming, e.g. until 31 August 1941, until 31 December 1941, until 31 March 1942, until 30 June 1942, which means that each time, Pchalek's superiors

10 BA, R 3001/70439, pp. 13-14, Schreiben des Oberlandesgerichtspräsidenten an den Reichsminister der Justiz betr. Übernahme des Assessors Gerhard Pchalek als Anwärter für das Amt des Richters oder des Staatsanwalts vom 28. Juni 1939 [Letter from the President of the Higher National Court in Wrocław to the Reich Minister of Justice on accepting assessor Gerhard Pchalek as a candidate for the office of a judge or prosecutor of 28 June 1939].

11 BA, R 3001/70439, p. 18, Schreiben des Reichsministers der Justiz vom 25. August 1939 [Communication of the Reich Minister of Justice of 25 August 1939].

12 BA, R 3001/70439, pp. 24-25, Personal- und Befähigungsnachweisung [Personal and qualifications evidence].

13 Ibidem, p. 25.

14 BStU Außenstelle Gera, MfS/Bezirksverwaltung Gera, AUV 38/59, HA Bd. II, p. 179, Schlussbericht vom 23. Juli 1959 [Final report of 23 July 1959].

15 BA, R 3001/70439, p. 29, Schreiben des Reichsministers der Justiz betr. Ernennungsurkunde vom 15. Juli 1941 [Communication from the Reich Minister of Justice concerning the appointment letter of 15 July 1941].

16 BA, R 3001/70439, p. 36, Schreiben des Generalstaatsanwalts in Kattowitz an das Wehrbezirkskommando in Bielitz vom 10. Dezember 1941 [Communication from the Attorney General in Katowice to the military district command in Bielsko of 10 December 1941]. 
had to apply for extension of the release from military service. Apart from the previous reasons for release, there was also a growing number of cases brought against the military economy and the establishment of Sondergericht Bielitz on 1 September 1942. The prosecuting authority was the prosecutor's office at the National Court in Bielsko and Pchalek, who specialised in economic matters, supported indictments before the Sondergericht. In December 1942, the General Prosecutor in Katowice made it clear that Pchalek was indispensable in the prosecutor's office in Bielsko and that he should be considered as the key person in that office. ${ }^{17}$

Pchalek represented the prosecution before the special courts in Bielsko and Katowice. ${ }^{18} \mathrm{He}$ substituted for Bielsko and Katowice prosecutors who were on leave and in March 1944, he was delegated to the General Prosecutor's Office in Katowice. His job was to supervise the subsidiary units of the prosecution and handle political criminal cases. In 1945, in order to avoid being drafted to Wehrmacht, he applied to Volkssturm. He went to Dresden and later to Gera. ${ }^{19}$ Gera was designated as the liquidation site for the Higher National Court in Katowice and the General Prosecutor's Office in Katowice. The tasks of the liquidation sites for the criminal justice authorities evacuated from the East were to transfer pending cases to courts in the Reich, to settle appeal cases and to solve the issue of the location of prisoners and personnel. ${ }^{20}$ In Gera, Pchalek was engaged in the criminal cases of the General Prosecutor's Office in Katowice until the end of the war. ${ }^{21}$

In mid-May 1945, Pchalek was appointed by the Mayor of Gera as the chief prosecutor in Gera. In September 1945, he joined the Social Democratic Party of Germany and after it merged with the Communist Party of Germany, he became a member of the new Socialist Unity Party of Germany. In November 1945, he was appointed the superintendent prosecutor. From 1946, he was the Deputy General Prosecutor of Thuringia, and from the turn of 1948, he was the chief of the General Prosecutor's Office. In 1950, he became the chair of the Criminal Senate at the Higher National Court in Erfurt. In 1952, he became the head of the Department

17 BA, R 3001/70439, p. 44, Schreiben des Generalstaatsanwalts in Kattowitz an das Wehrbezirkskommando in Bielitz vom 1. Dezember 1942 [Communication from the Attorney General in Katowice to the military district command in Bielsko of 1 December 1942].

18 BStU Außenstelle Gera, MfS/Bezirksverwaltung Gera, AUV 38/59, Haftsache II, p. 222, Anklageschrift gegen Gerhard Pchalek vom 16. Dezember 1959 [Indictment against Gerhard Pchalek of 16 December 1959].

19 BStU Außenstelle Gera, MfS/Bezirksverwaltung Gera, AUV 38/59, HA Bd. II, pp. 179-180, Schlussbericht vom 23. Juli 1959 [Final report of 23 July 1959].

20 Graczyk, K., Ewakuacja Sąu Specjalnego w Bielsku (Sondergericht Bielitz) w świetle raportów urzędnika bielskiej prokuratury z 1945 roku, "Szkice Archiwalno-Historyczne" 2017, No. 14, p. 151.

21 BStU Außenstelle Gera, MfS/Bezirksverwaltung Gera, AUV 38/59, HA Bd. II, p. 180, op. cit. 
of Criminal Law at the Friedrich Schiller University of Jena. He remained in that office until his arrest. ${ }^{22}$

After being convicted in criminal proceedings (discussed hereinabove) and serving a part of his sentence, Pchalek was released in 1962. He started working in the legal department of the state-owned enterprise VEB Zeiss, which specialised in the manufacture of high precision devices. At that time, he secretly collaborated with the Ministry of National Security of the German Democratic Republic. In 1978, he retired. He died in 1980 in Gera. ${ }^{23}$

\section{Criminal liability of Nazi judges and prosecutors}

The surviving memories suggest that for a number of years after the end of the war, judges and prosecutors who had worked in special courts experienced social condemnation. Their service was considered as a stain on state honour. ${ }^{24}$ In terms of their criminal liability for the judgments they had passed, a total of 22 trials against judges and prosecutors of the Third Reich were conducted before the courts of the German Federal Republic. However, no final judgment convicting a judge adjudicating in a special court or a prosecutor appearing before such court was passed. ${ }^{25}$

This happened even despite the conviction of high officials of the Third Reich justice system in the Nuremberg Trials: judges (including three special court judges ${ }^{26}$ and prosecutors. Nazi jurists were accused of war crimes and even crimes against humanity. What was important in those trials was that the American Mili-

22 BStU Außenstelle Gera, MfS/Bezirksverwaltung Gera, AUV 38/59, HA Bd. II, p. 180, op. cit. Riegel, P., op. cit., pp. 13-15.

23 Riegel, P., op. cit., pp. 55-59, 71.

24 Bundesarchiv Bayreuth, OSTDOK 8/211, p. 6, Bericht von Kurt Bode vom 1. Dezember 1953 [Kurt Bode's report of 1 December 1953]. In September 1939, Dr. Kurt Bode presided over two court trials against defenders of the Polish post office in Gdańsk, as a result of which 38 Poles were sentenced to death. These sentences were carried out. Both proceedings were a court crime. In the years 1942-1945, Bode was the Prosecutor General in Gdańsk. After the war, he was employed in the justice system of the Federal Republic of Germany. Schenk, D., Poczta polska w Gdansku. Dzieje pewnego niemieckiego zabójstwa sądowego, Gdańsk 1999, pp. 93, 99-100, 169, 191, 228-229.

25 Kulesza, W., op. cit., pp. 132-133. Kulesza determined that final convictions were passed in cases against individuals accused of judicial crimes, who had sentenced to death persons prosecuted before summary courts. Accordingly, participation in issuing the death penalty by a summary court was qualified as complicity (participation) in homicide.

26 Diestelkamp, B., Die Justiz nach 1945 und ihr Umgang mit der eigenen Vergangenheit, in: Diestelkamp, B. and Stolleis, M. (eds.), Justizalltag im Dritten Reich, Frankfurt am Main 1988, p. 134. 
tary Tribunal adjudicated solely on the basis of the Allied Control Council Law on the Punishment of Persons Guilty of War Crimes, Crimes Against Peace and Against Humanity of 20 December $1945 .{ }^{27}$ This Law being the legal and substantive basis for convictions, made it possible to dismiss the claims of the defense attorneys that defendants could not be considered guilty since they had acted in compliance with the law that was in force at the time of their service. According to the Allied Control Council Law, crimes against humanity were recognised as crimes whether or not they were in violation of the domestic laws of the country where perpetrated. The Tribunal ruled that a Nazi judge who convicted defendants to the death penalty on the grounds of their being a Pole or a Jew committed murder and that the law that enabled it constituted a crime against humanity and a war crime. ${ }^{28}$

Meanwhile, according to the approach adopted by the West German judiciary with respect to Nazi lawyers who had issued the death penalty during the Third Reich, "what had been legal back then could not be considered illegal now." The judges and prosecutors of special courts were not convicted, even despite the principles of the criminal liability of Third Reich judges dogmatically defined by Gustav Radbruch on the grounds of the German criminal law, and specifically $₫ 336$ of the StGB (Strafgesetzbuch - the German Criminal Code) ${ }^{29}$ on bending the law. According to the Radbruch formula:

The conflict between justice and the reliability of the law should be solved in favour of the positive law, law enacted by proper authority and power, even in cases where it is unjust in terms of content and purpose, except for cases where the discrepancy between the positive law and justice reaches a level so unbearable that the statute has to make way for justice because it has to be considered erroneous law. It is impossible to draw a sharper line of demarcation between cases of legal injustice and statutes that are applicable despite their improper content; however, another line of demarcation can be drawn with rigidity: Where justice is not even strived for, where equality, which is the core of justice, is renounced in the process of legislation; there a statute is not just 'erroneous law', it is in fact not of a legal nature at all..$^{30}$

27 Kontrollratsgesetz Nr. 10 - Bestrafung von Personen, die sich Kriegsverbrechen, Verbrechen gegen den Frieden oder gegen die Menschlichkeit schuldig gemacht haben vom 20. Dezember 1945 [Control Council Act no. 10 - punishment of persons guilty of war crimes, crimes against peace and against humanity of 20 December 1945]. Amtsblatt des Kontrollrats in Deutschland 1945, p. 50. Cyprian, T. and Sawicki, J., Nieznana Norymberga. Dwanaście procesów norymberskich, Warszawa 1965, pp. 87-132; Kulesza, W., op. cit., p. 41, 503.

29 Strafgesetzbuch für das Deutsche Reich [Criminal Code for the German Reich of 15 May 1871].

30 Zajadło, J., Radbruch, Sopot 2016, p. 24; Zajadło, J., Formuła Radbrucha. Filozofia prawa na granicy pozytywizmu prawniczego i prawa natury, Gdańsk 2001, passim. 
However, the case law, despite Radbruch's intention, limited the scope of application of the crime of bending the law. The Federal Court of Justice determined in its ruling of 1956 that bending the law was a crime only if it was committed with direct intention and not with possible intention. This meant the need to verify whether Nazi jurists intentionally bended the law that was in force in the Third Reich when issuing their judgements. The designatum of the concept of bending the law was falsification of the core of the matter being adjudicated, legally unjustified subsumption of facts and abuse of the judge's freedom of discretion when issuing the death penalty. Nonetheless, the accused lawyers successfully defended themselves claiming that they had issued the death penalty being convinced that their judgments were in compliance with the law and that their intention was to serve the German nation in a situation of danger caused by the ongoing war.

It is claimed that the reason for the failure to serve justice to Nazi judges and prosecutors in the German Federal Republic were the high requirements established in the case law concerning the subjective traits of the crime of bending the law (the requirement to prove direct intention), which were very hard to satisfy due to lack of sufficient evidence. Another factor, not connected with the law, was the reluctance of post-war lawyers in Western Germany to prosecute and punish their Nazi colleagues. After all, they represented the same profession and the same social class and often had similar "brown" pasts. ${ }^{31}$

While no Nazi lawyer was convicted in the criminal trials conducted in the German Federal Republic, there was at least one such case involving a prosecutor in a special court in the German Democratic Republic.

\section{Criminal trial against Gerhard Pchalek}

In February 1959, there was an exhibition in Erfurt devoted to "bloody courts" and "bloody judges", i.e. judges and prosecutors of special courts from the period of the Nazi regime. The purpose was to stigmatise them for the judgments they

31 Kulesza, W., op. cit., pp. 77-78, 85, 134-135, 503-505. It should be noted that on 8 of May 1960, the 15-year limitation period of homicide, bodily injury leading to death, illegal deprivation of liberty leading to death and robbery had ended. There was a risk that the limitation period of crimes punished by life in prison, including murder, would expire on 8 May 1965. The Act of 25 March 1965 on Calculating Criminal Periods of Prescription excluded the time between 8 May 1945 to 31 December 1949 from those periods, meaning that Nazi crimes would prescribe on 31 December 1969. The amendment of 26 May 1969 extended the period of prescription for crimes punished by life imprisonment from twenty to thirty years, which delayed the prescription of murders committed by the Nazi to the end of 1979. Finally, the amendment of 16 July 1979 determined that Nazi murders would not have a prescription period. Kulesza, W., op. cit., pp. 95-96. 
had passed during the Third Reich, the more so that at the time of the exhibition, they held public offices in the German Federal Republic, also in the judiciary. In that exhibition, one student noticed a facimile of a judgment passed by the Higher National Court in Katowice on 27 June 1944 against a 62-year-old farmer Ignacy Kaczmarek. ${ }^{32} \mathrm{He}$ had been sentenced to death for undermining the military forces (Wehrkraftzersetzung). The judgement bore the name of Prosecutor Pchalek. The student associated the name with Gerhard Pchalek, the lecturer on criminal law, and she informed the District Prosecutor in Erfurt of her discovery. ${ }^{33}$

On 18 and 19 February 1959, the facimile was discussed at a meeting of party and prosecution members, which was also attended by a representative of the Ministry on National Defence of the German Democratic Republic. They wondered what to do next. One of the suggestions was to arrest Pchalek immediately, which, however, was problematic because the consent of the security department was needed. Still, it was important not to let Pchalek flee the country. It was therefore decided that two prosecutors, at the instruction of the district prosecutor, would go to Pchalek and bring him back to Gera for a "conversation". Eventually, the conversation ended in an interrogation at the district prosecutor's office. ${ }^{34}$

The object of the interrogation was Pchalek's activity at the General Prosecutor's Office in Katowice during the war. Initially, he claimed that he had only been involved in economic crimes, but he later added that, at the order of his superiors, he had also worked on cases against treason, undermining military force and socalled radio crimes. ${ }^{35} \mathrm{He}$ also admitted that in five to ten cases he had requested the death penalty at the order of his superiors, and the court had ruled accordingly. He claimed that if he had not done so, he would have suffered serious personal consequences. ${ }^{36}$

Pchalek was detained on 19 February 1959. On 20 February 1959, the County Court (Kreisgericht) in Gera issued an arrest warrant for him. At a hearing in his case, Pchalek maintained what he had said before and as a mitigating circumstance, he claimed that he had requested the death penalty only at the order of his superiors

32 The case was presented by Wolfgang Koppel in his study on death penalties issued by special courts. Koppel, W., Ungesühnte Nazijustiz. Hundert Urteile klagen ihre Richter an, Karslruhe 1960, p. 20.

33 Riegel, P., op. cit., p. 40.

34 Ibidem, pp. 40-41.

35 For radio crimes, see: Konieczny, A., Problem przestępstw radiowych w rejencji katowickiej w latach 1939-1945, "Studia Historycznoprawne", vol. CCXXIII, pp. 195-215.

36 Riegel, P., op. cit., p. 41. 
and that, in a few cases, he had not requested the death penalty even despite being ordered to do so. ${ }^{37}$

The indictment was made on 16 December 1959. Pchalek was accused of "destroying human life in appr. 20 cases by aiding murder in the period from 1941 to 1944". According to the prosecution, in that period of time, Pchalek requested the death penalty before special courts in Katowice and Bielsko for German and Polish patriots and, in most cases, "bloody Fascist judges" consented to those requests. The judgments were then executed and Pchalek supervised several of the executions. Moreover, as an assistant of the General Prosecutor in Katowice, he ordered his subordinate prosecutors to request the death penalty. He also reviewed prison sentences and recommended appealing against them using the special legal measure - complaint of invalidity (Nichtigkeitsbeschwerde). If, in his opinion, the convicted deserved the death penalty, those sentences were repealed, the trial was repeated and the death penalty was adjudicated. The alleged act was qualified pursuant to $₫ 211$ of the StGB (concerning murder), in association with $₫ 49$ of the StGB (concerning power of attorney). ${ }^{38}$

The indictment listed specific cases in which Pchalek as the prosecutor had demanded the death penalty and in which it had been adjudicated, e.g. against a woman who had helped her friend acquire weapons in order to fight the German fascism, or against a resistance group whose members included a chaplain and the farmer Ignacy Kaczmarek. ${ }^{39}$ Pchalek's supervisory activity at the prosecutor's office in Katowice was elaborated on. Many times, despite the proposals of his subordinate prosecutors to petition for a penalty of strict prison, he had demanded the death penalty. In two cases from the case law of the Sondergericht Kattowitz, Pchalek had demanded the capital punishment, but the court had adjudicated much milder sentences: six and four years of severe prison, respectively. It was refuted that Pchalek had requested the death penalty only at the order of his superiors, presenting as evidence the case of Julian Szynder sentenced to the capital punishment on 20 June 1944 by the Higher National Court in Katowice. It was also noted that Pchalek had applied the Regulation on the criminal law for Poles and Jews in the incorporated

37 BStU Außenstelle Gera, MfS/Bezirksverwaltung Gera, AUV 38/59, Haftsache GA Bd. I, p. 7, Einlieferungsanzeige vom 19. Februar 1959 [Notice of compulsory appearance of 20 February 1959]; p. 12, Haftbefehl vom 20. Februar 1959 [Indictment of 20 February 1959]; p. 13, Verhandlungsprotokoll vom 20. Feberuar 1959 [Minutes of the hearing of 20 February 1959].

38 BStU Außenstelle Gera, MfS/Bezirksverwaltung Gera, AUV 38/59, Haftsache GA Bd. II, pp. 1-2, Anklageschrift vom 16. Dezember 1959 [Indictment of 16 December 1959].

Ibidem, pp. 5-6. 
Eastern areas of 4 December $1941 .{ }^{40}$ This meant that Pchalek had consistently supported the fascist criminal policy, which could not be reconciled either with the principles of the international law or humanitarianism. In the opinion of the author of the indictment, Pchalek, even though not the perpetrator himself, had assisted the immediate murderers, i.e. the fascist state, by the motions he had filed as the prosecutor. The evidence supplied by the prosecutor included, in particular, documentation (case files and sentences) and testimony of three witnesses, including former officials of the prosecutor's office in Bielsk. ${ }^{41}$

Gerhard Pchalek's act was qualified as aiding in murder pursuant to $\$ 211$ of the StGB, in association with $₫ 49$ of the StGB. The crime of murder was defined in $\$ 211$ section 2 of the StGB. According to that provision, a murderer was one who killed a person: a) out of bloodlust, sexual desire, greed or other low motives; b) insidiously or cruelly, or by using means posing general danger; c) or to enable or conceal another crime. A different provision $-\$ 212$ of the StGB - established a milder punishment for murder, understood as intentionally killing a person without premeditation (Überlegung). Meanwhile, according to $₫ 49$ section 1 of the StGB, a punishment could be served on one who knowingly helped the perpetrator commit a crime or offence through act or advice. In addition, as stated in $\$ 49$ section 2 of the StGB, the punishment for the helper was to be determined according to the relevant regulation governing a specific action that one knowingly helped, however, reduced according to the principles governing punishment for 'attempt'.

On 2 February 1960, a decision was issued to open the main proceedings against Pchalek before the Criminal Senate of the District Court in Gera. The main trial was held on 5 April 1960 before a mixed adjudicating panel consisting of one professional judge and two jurors. The defendant Pchalek was brought from custody. He was defended by two hired lawyers. At the prosecutor's request, the proceedings were held in camera. Following the taking of evidence, the prosecutor requested the penalty of 4 years of strict regime prison, minus the time already served in detention, while the two lawyers petitioned for a milder sentence, taking into account the defendant's merits after 1945. The judgement was announced on 8 April 1960.

40 Verordnung über die Strafrechtspflege gegen Polen und Juden in den eingegliederten Ostgebieten vom 4. Dezember 1941 [Regulation on the criminal law for Poles and Jews in the incorporated Eastern areas of 4 December 1941] RGBl. 1941, p. 759. The International Military Tribunal at Nuremberg declared the Regulation on the criminal law for Poles and Jews in the incorporated Eastern areas to have been illegal and against the Hague Conventions, as its adoption and implementation involved racial persecution and extermination in areas annexed in the course of a criminal and aggressive war. Kulesza, W., op. cit., p. 44.

41 BStU Außenstelle Gera, MfS/Bezirksverwaltung Gera, AUV 38/59, Haftsache GA Bd. II, pp. 6-8, op. cit. 
Gerhard Pchalek was sentenced for aiding the murder in 20 cases pursuant to $\$ 211$ of the StGB, in association with $₫ 49$ of the StGB to 4 years of strict regime prison, minus the time already served in detention. ${ }^{42}$

The 16-page-long judgment with a statement of justification confirmed the findings of the prosecutor presented in the indictment and even intensified many of their aspects. Pchalek was assessed as a social climber who, despite not being a formal member of the NSDAP, enjoyed huge trust of his superiors. Thanks to that trust, in 1942, he was appointed as the permanent representative of the prosecutor's office at Sondergericht Bielitz and moved to the second division of the prosecutor's office for political cases. When serving in that division, he filed motions for the death penalty for five persons, even though he was aware that the punishment was grossly disproportionate to the acts committed by them. He requested the death penalty for 15 other persons when he was delegated to the General Prosecutor's Office, where he controlled all the economic cases in the region. He filed the last motion for the death penalty for three Polish patriots in December 1944, when it was already evident that Hitler's regime was bound to collapse soon. Based on this, the court determined that Pchalek actively promoted the fascist policy of destruction until its last moments. ${ }^{43}$

A lot of attention was devoted to the takeover of power in Germany by national socialists, the unleashing of World War II and fascist crimes. Those fragments of the judgment bear the political imprint of the period when they were written. This is proven both by the language used and references to the activity of the Communist Party of Germany, and the national ideology of the German Democratic Republic. Meanwhile, the statement of justification fails to elaborate on the legal qualification. The legal qualification proposed by the prosecutor was approved in its entire extent. The penalty was affected, on the one hand, by the high social harmfulness of Pchalek's actions and, on the other hand, by his work for the society after $1945 .{ }^{44}$

P. Riegel noted that the judgement in Pchalek's case involved consultation not only with the Central Committee of the Socialist Unity Party of Germany but, most likely, also with the defendant himself. This would explain to some extent the fact

42 BStU Außenstelle Gera, MfS/Bezirksverwaltung Gera, AUV 38/59, Haftsache GA Bd. II, pp. 15-18, Eröffnungsbeschluss vom 2. Februar 1960 [Decision on opening the main proceedings of 2 February 1960]; pp. 37-43, Hauptverhandlungsprotokoll vom 5. April 1960 [Minutes of the main hearing of 5 April 1960].

43 BStU Außenstelle Gera, MfS/Bezirksverwaltung Gera, AUV 38/59, Haftsache GA Bd. II, pp. 55-56, 62, Urteil in der Strafsache gegen Gerhard Pchalek vom 8. April 1960 [Judgement in the criminal case against Gerhard Pchalek of 8 April 1960].

44 Ibidem, pp. 56-61. 
that Pchalek did not appeal against the judgement of the court of the first instance. ${ }^{45}$ In June 1962, the convict was released on parole after two years on the grounds of good behaviour. ${ }^{46}$

\section{Conclusion}

It is common knowledge that a vast majority of lawyers from the Third Reich found employment in the judiciary of the German Federal Republic. Unfortunately, none of them were prosecuted by the German criminal justice system. This was notwithstanding the dogmatic definition of the grounds for such liability determined by Gustav Radbruch as a result of the high standard of proof established by the case law of the Federal Court of Justice. This required proving the judge's or prosecutor's intention of direct deprivation of defendant's life regardless of the substantive conditions of a given case. So this was about a situation in which a Nazi judge a priori intended to convict the defendant to the death penalty, regardless of evidence, e.g. on the grounds of their nationality, political views, etc. Consequently, even though Radbruch's formula laid foundations for invoking the crime against humanity and initiating proceedings against Nazi criminals, and it actually functioned in proceedings before the International Military Tribunal in Nuremberg, ${ }^{47}$ it proved useless in confrontation with Nazi lawyers.

The problem of the criminal liability of Nazi lawyers was settled differently in the German Democratic Republic. In the Soviet occupation zone of Germany, the first judgement convicting judges of the Higher National Court in Dresden who had imposed draconian penalties pursuant to regulations on the treason and betrayal of the country, mainly against forced labourers who had tried to escape from places of slave labour, and prosecutors who had filed final motions in those proceedings, was already passed in 1947 . The Nazi lawyers were mildly sentenced to imprisonment ranging between one year and two months and six years. The legal basis for the judgement was the abovementioned Act of the Allied Control Council Law on the Punishment of Persons Guilty of War Crimes, Crimes Against Peace and Against Humanity of 20 December 1945 and $\$ 336$ of the StGB. In the German Democratic Republic, Nazi lawyers received "flat-rate" (W. Kulesza) sentences in

45 Riegel, P., op. cit., p. 55.

46 BStU Außenstelle Gera, MfS/Bezirksverwaltung Gera, AUV 38/59, Haftsache GA Bd. II, p. 84, Beschluss vom 14. Juni 1962. [Decision of 14 June 1962].

47 Lubertowicz, M., Lex iniustissima non est lex: formuła Gustava Radbrucha jako alternatywa dla międzynarodowego systemu ochrony praw człowieka, "Studia Erasmiana Wratislaviensia" 2010, No. 4, pp. 364-366. 
trials held in Waldheim between April and July 1950, which resulted in 3,324 convictions of imprisonment for 10 to 25 years. In those cases, the only legal basis for the convictions was the Act of the Allied Control Council Law on the Punishment of Persons Guilty of War Crimes, Crimes Against Peace and Against Humanity of 20 December 1945, but accusations extended to membership in the NSDAP or civil service in the Third Reich, which was associated with responsibility for implementing the goals of the Nazi state, as well as participation in war crimes and crimes against humanity. However, those trials were in violation of the substantive and procedural law and in themselves, they were an example of bending the law by judges in criminal proceedings. ${ }^{48}$

Gerhard Pchalek's case discussed in this paper differs from previous attempts to prosecute Nazi lawyers. Pchalek himself was specific, because, after the end of World War II, he managed to conceal the details of his work at the prosecutor's office in Upper Silesia from 1941 to 1944 and, since he had never been a member of the NSDAP, he could perform managerial functions in the reconstructed judiciary of East Germany. The criminal case against him started by accident, though, there was a political factor involved, because Pchalek was a member of the Socialist Unity Party of Germany and held certain functions in it. The legal evaluation in the criminal trial before the District Court in Gera was different than in the Nuremberg trial or the Waldheim trials of lawyers. Instead of the extraordinary regulations passed after the end of World War II, concerning war crimes and crimes against humanity or $\$ 336$ of the StGB governing the crime of bending the law, it was based on $\S$ 211 of the StGB concerning murder, in association with $₫ 49$ of the StGB concerning aiding in murder. The District Court in Gera determined that Pchalek, filing motions for the death penalty for twenty persons in trials before the Special Court in Bielsk, the Special Court in Katowice and the Higher National Court in Katowice, had committed the crime of aiding in murder, because the defendants had been convicted accordingly and the sentences had been executed. The penalty of 4 years of strict regime prison was low, the more so that Pchalek was released on parole, most probably due to political factors. However, his case has a symbolic dimension in the first place. It proves that it was possible to prosecute a Nazi lawyer.

48 Kulesza, W., op. cit., pp. 47-54. 


\section{References}

Cyprian, T. and Sawicki, J., Nieznana Norymberga. Dwanaście procesów norymberskich, Warszawa 1965.

Diestelkamp, B., Die Justiz nach 1945 und ihr Umgang mit der eigenen Vergangenheit, in: Diestelkamp, B. and Stolleis, M. (eds.), Justizalltag im Dritten Reich, Frankfurt am Main 1988.

Graczyk, K., Ewakuacja Sądu Specjalnego w Bielsku (Sondergericht Bielitz) w świetle raportów urzędnika bielskiej prokuratury z 1945 roku, "Szkice Archiwalno-Historyczne" 2017, No. 14.

Gruchmann, L., Justiz im Dritten Reich 1933-1940. Anpassung und Unterwerfung in der Ära Gürtner, München 2001.

Konieczny, A., Problem przestępstw radiowych $w$ rejencji katowickiej w latach 1939-1945, "Studia Historycznoprawne", Vol. CCXXIII.

Koppel, W., Ungesühnte Nazijustiz. Hundert Urteile klagen ihre Richter an, Karslruhe 1960.

Kulesza, W., Crimen laesae iustitiae. Odpowiedzialność karna sędziów i prokuratorów za zbrodnie sądowe według prawa norymberskiego, niemieckiego, austriackiego i polskiego, Łódź 2013.

Lubertowicz, M., Lex iniustissima non est lex: formuła Gustava Radbrucha jako alternatywa dla międzynarodowego systemu ochrony praw człowieka, "Studia Erasmiana Wratislaviensia" 2010, No. 4.

Riegel, P., Der Tiefe Fall des Professors Pchalek - Diener dreier Unrechtssysteme. Ein Thüringer Jurist zwischen NS-Justiz, Besatzungsmacht, Rechtsprofessur und Spitzeldienst, Erfurt 2007.

Schenk, D., Poczta polska w Gdańsku. Dzieje pewnego niemieckiego zabójstwa sądowego, Gdańsk 1999.

Zajadło, J., Formuła Radbrucha. Filozofia prawa na granicy pozytywizmu prawniczego i prawa natury, Gdańsk 2001.

Zajadło, J., Radbruch, Sopot 2016.

\section{CITATION}

GRACZYK, K., Convicted Nazi lawyer. The case of Gerhard Pchalek in the Gera District Court in 1960, “Acta Iuris Stetinensis" 2020, No. 1 (Vol. 29), 17-31, DOI: 10.18276/ais.2020.29-02. 